\title{
Rancang bangun sistem peringatan kemiringan menara dan overload jembatan gantung berbasis sensor kemiringan dan sensor massa
}

\author{
Haris Saefurrahman*, Hartono, dan Farzand Abdullatif \\ Program Studi Fisika, Fakultas MIPA, Universitas Jenderal Soedirman \\ Jalan Dr. Suparno No.61 Grendeng Purwokerto Jawa Tengah \\ *email: harissaefurrahman22@gmail.com
}

\begin{abstract}
Abstrak - Jembatan gantung sangat penting sebagai sarana transportasi. Namun perlu pemantauan agar kontruksi jembatan aman bagi pengguna. Akibat beban lebih seringkali jembatan gantung mengalami kemiringan bahkan roboh. Oleh karena itu perlu sistin peringatan dini. Tujuan penelitian ini adalah merancang sistem peringatan kemiringan dan overload pada jembatan gantung secara otomatis. Rancangan sistem memanfaatkan sensor Load Cell sebagai alat pengukur massa dan sensor kemiringan MPU6050 sebagai alat pengukur kemiringan. Disamping itu memanfaatkan mikrokontrol arduino sebagai pusat kendali sistem elektronika, sekaligus sebagai pengatur fungsi logika peringatan untuk mengaktifkan LED, buzzer dan LCD. Hasil pengujian karakteristik statik sensor kemiringan dan sensor massa memiliki rata-rata nilai akurasi sebesar $96,39 \%$ dan $99,55 \%$, presisi sebesar $96,33 \%$ dan $99,55 \%$, error sebesar 3,61\%dan $0,45 \%$ serta waktu respon sebesar 1 detik dan 2 detik. sensor load cell dan sensor kemiringan memiliki sensitifitas tingi. Hasil rancang bangun sistem peringatan kemiringan menara dan overload jembatan gantung menggunakan sensor kemiringan dan sensor massa dapat bekerja dengan baik. UJi coba menunjukkan kedua sensor telah mampu memberikan peringatan dini apabila sensor mendeteksi kemiringan melebihi $1,11^{\circ}$ dan beban melebihi 500 gram.
\end{abstract}

Kata Kunci:, kapasitansi, larutan elektrolit, membran

\begin{abstract}
Suspension bridges are very important as a means of transportation. However, monitoring is needed so that the bridge construction is safe for users. As a result of more loads, suspension bridges often tilt and even collapse. Therefore, an early warning system is needed. The purpose of this study is to design a slope and overload warning system on a suspension bridge automatically. The system design utilizes the Load Cell sensor as a mass measuring device and the MPU6050 tilt sensor as a slope measuring device. Besides that, it utilizes the Arduino microcontroller as the control center of the electronic system, as well as controlling the warning logic function to activate the LED, buzzer and LCD. The results of testing the static characteristics of the tilt sensor and mass sensor have an average accuracy value of $96.39 \%$ and $99.55 \%$, a precision of $96.33 \%$ and $99.55 \%$, an error of $3.61 \%$ and $0.45 \%$ and response time of 1 second and 2 seconds. load cell sensor and tilt sensor have high sensitivity. The results of the design of the tower slope warning system and suspension bridge overload using tilt sensors and mass sensors can work well. Tests show that both sensors have been able to provide early warning if the sensor detects a slope exceeding $1.11^{\circ}$ and a load exceeding 500 grams.
\end{abstract}

Keywords: Slope of towers, suspension bridge, overload, MPU6050 sensors, load cell sensor.

\section{PENDAHULUAN}

Jembatan gantung adalah jembatan yang berfungsi sebagai penghubung dua bagian jalan yang terputus oleh sungai atau jurang. Ketersediaan jembatan gantung sebagai salah satu prasarana transportasi diperlukan guna menunjang kelancaran arus lalu lintas di daerahdaerah. Guna menjamin keselamatan dan kenyamanan pengguna diperlukan peninjauan kelayakan kontruksi jembatan gantung tersebut. Peninjauan rutin jembatan bekontribusi terhadap umur jembatan. Disamping itu masih ada faktor lain yang menyebabkab pengurangan umur jembatan [1].
Salah satu faktor yang dapat mengurangi umur jembatan menjadi tidak sesuai dengan umur rencana awal yaitu overload. Pembebanan berlebih (overload) terjadi karenat pengguna jembatan mengabaikan beban yang dibawanya. Dampak dari pembebanan berlebih jembatan dapat mengalami kemiringan bahkan keruntuhan [2]. Seperti yang terjadi pada jembatan gantung Kutai Kartanegara yang mengalami keruntuhan. Menara jembatan Kutai Kartanegara mengalami kemiringan sebesar $1,11^{\circ}[3]$. Pengawasan jembatan gantung selama ini dilakukan dengan cara manual sehinga pengguna jembatan yang muatan lebih tidak dapat dipantau dengan akurat. Oleh karena itu, 
diperlukan sistem peringatan yang dapat memantau kondisi jembatan baik itu beban pengguna jembatan gantung maupun kondisi menara jembatan gantung.

Pada penelitian ini akan dibuat sistem peringatan kemiringan menara dan overload jembatan gantung berbasis sensor kemiringan dan sensor massa. Sensor kemiringan yang digunakan yaitu accelerometer, serta sensor Load Cell digunakan sebagai sensor deteksi beban sebagai beban bergerak atau beban hidup.

\section{METODE PENELITIAN}

Penelitian dilaksanakan di Laboratorium Elektronika Instrumentasi dan Geofisika dan Laboratorium Fisika Dasar, Fakultas Matematika dan Ilmu Pengetahuan Alam, Universitas Jenderal Soedirman. Penelitian dilakukan mulai November 2020 hingga Februari 2021.

Alat-alat yang digunakan pada penelitian ini terdiri dari arduino UNO, laptop, arduino IDE, busur, dan neraca digital. Bahan-bahan yang digunakan terdiri dari sensor kemiringan MPU6050, sensor load cell, buzzer, LCD 16 x 2, potensiometer, IC INA 114, LED dan. papan tripleks.

Penelitian dibagi menjadi empat tahapan. Pertama pengujian karakteristik statik sensor, yang terdiri dari pengujian massa terhadap tegangan keluaran sensor load cell dan pengujian sudut terhadap nilai ADC sensor kemiringan.

Tahap kedua adalah perancangan alat dan perangkaian sistem. Guna mempermudah dan memandu dalam merangkai komponen elektronika maka dibuat diagram blok seperti Gambar 1. Sensor Load Cell dan sensor kemiringan sebagai input sistem. Mikrokontroler berfungsi sebagai pengkondisi sinyal. Output dari sistem ditampilkan pada buzzer, LED (Light Emitting Diode), dan LCD. Realisasi rangkaian sistem elektronika berdasarkan blok diagram pada Gambar 1 ditunjukkan pada Gambar 2.

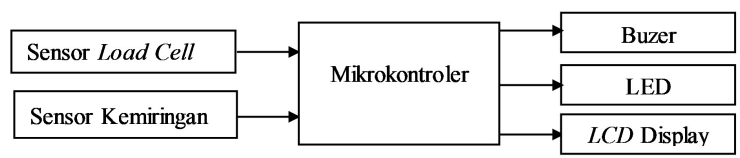

Gambar 1. Diagram blok guna memandu pembuatan sistem elektronika

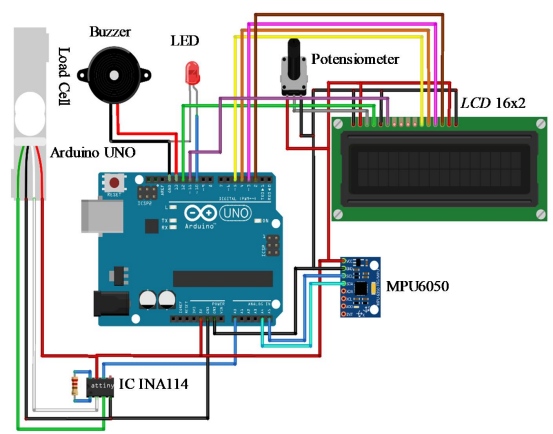

Gambar 2. Rancangan rangkaian sistem elektronika peringatan kemiringan menara dan overload jembatan gantung

Selanjutnya rangkaian sistem elektronika dirangkai pada jembatan gantung. LED dirancang menyala dan buzzer berbunyi apabila terjadi kelebihan beban dan kemiringan yang membahayakan. Desain sistem peringatan jembatan gantung diperlihatkan pada Gambar 3.

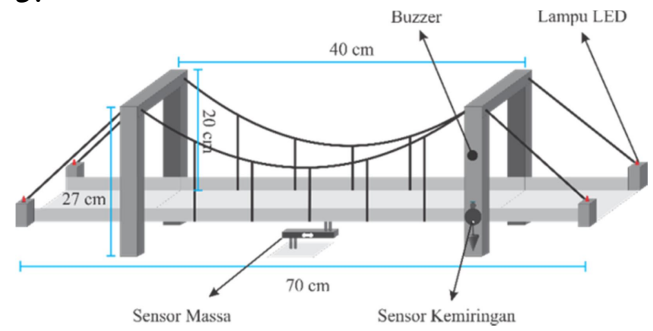

Gambar 3. Desain sistem peringatan jembatan gantung

Pada tahap ketiga dilakukan pembuatan program arduino. Program arduino dibuat menggunakan program Arduino IDE (Integrated Development Environment). Arduino diprogram pada keadaan tertentu agar memberikan sinyal ke aktuator. Terdapat 4 keadaan pada sistem logika program arduino.

Tahap terakhir yaitu pengujian sistem untuk memastikan bahwa seluruh rangkaian berjalan dengan baik. Komponen pertama yang diuji adalah sensor Load cell dengan membandingkan nilai massa dari sensor dengan neraca digital terkalibrasi. Serta komponen kedua yang diuji adalah sensor kemiringan seri MPU6050 dengan membandingkan nilai sudut dari sensor dengan sudut dari busur.

Uji model jembatan dilakukan pada skala laboratorium. Batas beban yang digunakan yaitu 500 gram, diasumsikan ketika beban melebihi 500 gram akan menyebabkan jembatan dalam kondisi bahaya. Batas kemiringan yang 
digunakan yaitu $1,11^{\circ}$ dengan mengacu pada kasus Jembatan Kutai Kartanegara.

\section{HASIL DAN PEMBAHASAN}

\section{Pengujian sensor Load cell dan sensor kemiringan}

Pengujian sensor Load cell dilakukan dengan menguji pengaruh beban terhadap tegangan keluaran sensor. Pengujian dilakukan menvariasikan beban pada rentang $0 \mathrm{~g}$ sampai 2000 g. Berdasarkan hasil pengujian diperoleh akurasi sensor Load Cell sebesar 98,83\% dan presisi $98,18 \%$. Hasil pengujian pembebanan terhadap tegangan keluaran sensor diperoleh kurva kalibrasi pada Gambar 4.

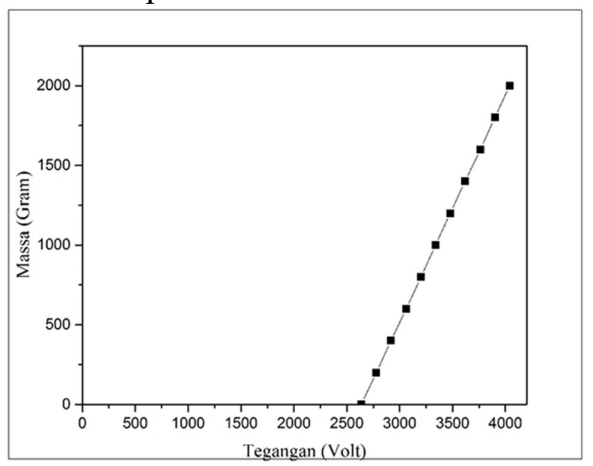

Gambar 4. Grafik fungsi kalibrasi sensor Load cell

Fungsi kalibrasi dari sensor Load Cell dapat diperlihatkan pada persamaan (4.1).

$$
\text { massa }=(1425,5 \times \text { tegangan })-3760,2(4.1)
$$

Sensor Load Cell bekerja dengan baik dan memiliki nilai korelasi yang tinggi yaitu 1 Hasil yang diperoleh sesuai penelitian sebelumnya [4].

Pada pengujian sensor kemiringan MPU6050 dilakukan dengan mengukur ADC keluaran dari sensor. Sudut penyimpangan sensor divariasikan mulai dari $0^{\circ}$ hingga $10^{\circ}$ dengan interval $1^{\circ}$. Pengulangan dilakukan sebanyak 20 kali. Hasil pengujian rata-rata akurasi sensor kemiringan sebelum ditambahkan gear box sebesar 98,06\% dan presisi 97,31\%. Hasil pengujian hubungan antara ADC keluaran sensor terhadap nilai sudut,diperoleh grafik kalibrasi seperti diperlihatkan pada Gambar 5.

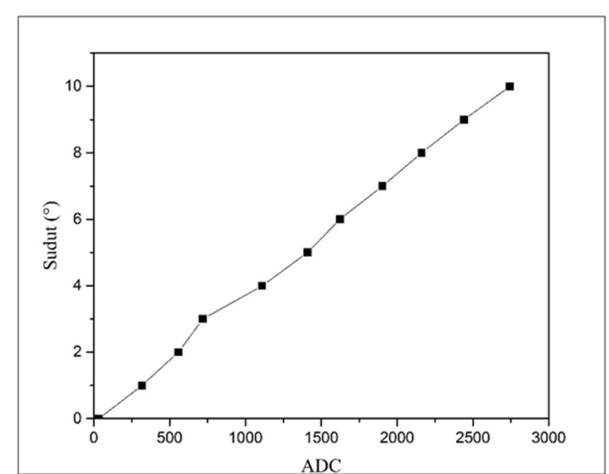

Gambar 5. Grafik fungsi kalibrasi sensor kemiringan

Sensor memiliki sensitivitas sebesar 271,2/ . Korelasi antara data yang didapatkan dengan fungsi liniernya sebesar 0,998. Batas kemiringan yang diizinkan adalah $1,11^{\circ}$. Dikarenakan batas sudut yang diizinkan sangat kecil maka sensitivitas sensor perlu ditingkatkan, yaitu dengan menambahkan geear box seperti pada Gambar 6.

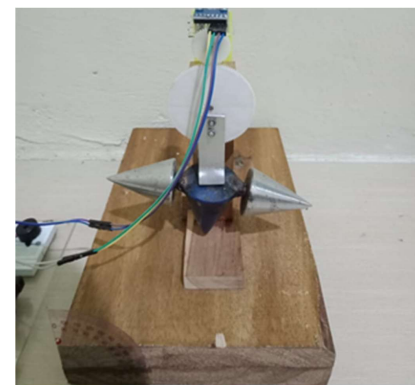

Gambar 6. Sensor yang sudah ditambahkan gear box

Sensor yang telah di tambahkan gear box memiliki rasio $1: 3$. Artinya perubahan $1^{\circ}$ pada busur sama dengan perubahan $3^{\circ}$ pada sensor. Hasil pengujian sensor setelah ditambahkan gear box menunjukkan rata-rata nilai akurasi sebesar 96,39\% dan presisi 96,33\%. Hubungan antara perubahan sudut dan ADC keluaran sensor didapatkan fungsi kalibrasi. Fungsi kalibrasi sensor ditunjukkan Gambar 7. 


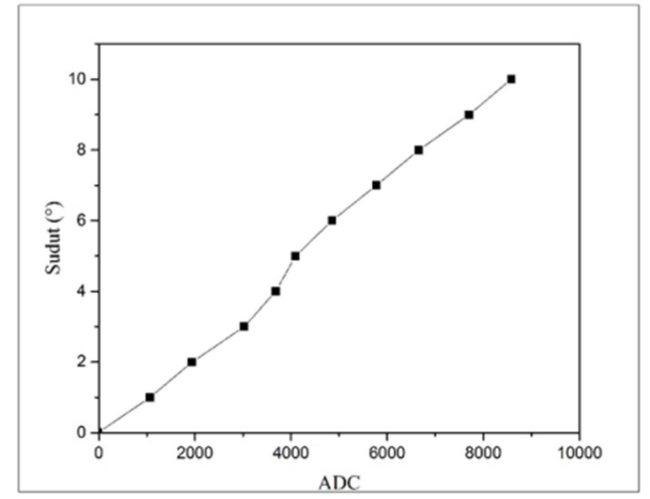

Gambar 7. Grafik fungsi kalibrasi sensor kemiringan MPU6050

Sensitivitas sensor meningkat dari $271,2{ }^{\circ}$ menjadi $859,96 /^{\circ}$. Gear box ditambahkan berhasil menjadikan sensor mendeteksi setiap perubahan $1^{\circ}$ lebih sensitif. Fungsi kalibrasi dari sensor kemiringan MPU6050 dapat dilihat pada persamaan ( 4.2 ).

$$
\text { sudut }=(0,0012 \times A D C)-0,2098
$$

\section{Pengujian program Arduino}

Hasil pengujian program Arduino dibuat mengunakan software Arduino IDE telah berjalan dengan baik. Arduino diprogram untuk beberapa fungsi. LED dan buzzer akan aktif apabila kemiringan terdeteksi melebihi $1,11^{\circ}$ dan nilai massa melebihi 500 gram. Fungsi logika telah berhasil memerintahkan untuk menyalakan LED, buzzer, dan menampilkan keterangan 'Kondisi: Aman' dan 'Kondisi: Bahaya' pada $L C D$. Program telah siap aplikasikan dalam sistem peringatan overload dan kemiringan jembatan gantung.

\section{Pengujian sistem peringatan overload dan kemiringan jembatan gantung}

Pembuatan model sistem peringatan kemiringan menara dan overload jembatan gantung dibagi menjadi beberapa tahapan. Pertama yaitu integrasi/ perangkaian komponen elektronika yang digunakan. Komponen tersebut dirangkai sesuai dengan skema rangkaian sistem elektronika pada Gambar 8. Tahap selanjutnya yaitu perangkaian keseluruhan komponen rancang bangun sistem.

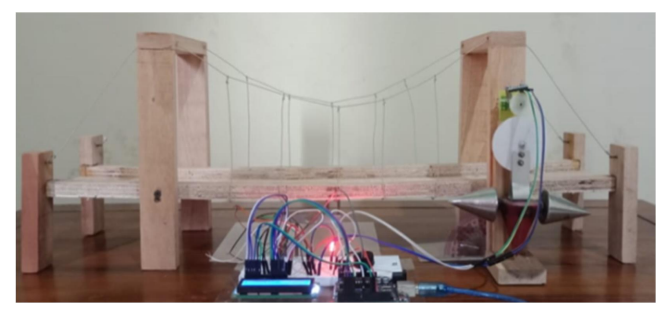

Gambar 8. Model sistem peringatan kemiringan menara dan overload jembatan gantung skala laboratorium

Setelah semua komponen sudah terintegrasi, selanjutnya dilakukan pengujian sistem dalam dua tahap. Tahap pertama yaitu menguji waktu respon serta notifikasi logika. Tahap kedua yaitu menguji sistem logika yang sudah ditetapkan pada kedua sensor.

Hasil pengujian sistem sensor Load Cell menunjukkan sistem bekerja dengan baik seperti penelitian yang dilakukan peneliti sebelumnya [4]. LED dan buzzer aktif pada pembacaan massa lebih dari 500 gram. Sistem peringatan overload jembatan gantung dengan sensor Load Cell memiliki akurasi rata-rata sebesar 99,55\%, presisi rata-rata sebesar $99,55 \%$, dan error rata-rata yang dimiliki sebesar $0,45 \%$.

Hasil pengujian sistem sensor kemiringan MPU6050 pada sistem peringatan kemiringan menara jembatan menunjukkan sistem bekerja dengan baik seperti penelitian sebelumnya [5]. LED dan buzzer aktif pada pembacaan sudut lebih dari $1,11^{\circ}$. Sistem peringatan kemiringan menara jembatan gantung dengan sensor MPU6050 memiliki akurasi rata-rata sebesar $96,39 \%$, presisi rata-rata sebesar $96,33 \%$, dan error rata-rata yang dimiliki sebesar 3,61\%.

Hasil pengujian sistem logika setelah divariasikan antara massa beban dan sudut kemiringan, menunjukkan hasil sistem logika yang dibuat dapat bekerja dengan baik sesuai fungsi logika yang dibuat. Fungsi logika yang pertama adalah jika massa beban terbaca oleh sensor massa kurang dari 500 gram dan kemiringan terbaca sensor kemiringan kurang dari $1,11^{\circ}$ maka $L E D$ dan buzzer tidak aktif serta $L C D$ menampilkan status aman. Fungsi logika kedua jika massa beban melebihi 500 gram dan kemiringan melebihi $1,11^{\circ}$ maka $L E D$ dan buzzer aktif serta $L C D$ menampilkan status bahaya. Fungsi logika ketiga jika massa kurang dari 500 gram dan kemiringan lebih dari $1,11^{\circ}$ maka LED dan buzzer aktif serta $L C D$ menampilkan status bahaya. Fungsi logika 
terakhir jika massa beban melebihi 500 gram dan kemiringan kurang dari $1,11^{\circ}$ maka $L E D$ dan buzzer aktif serta $L C D$ menampilkan status bahaya. Hasil dari pengujian sistem ini menunjukkan bahwa sistem dapat dijadikan sistem peringatan kemiringan menara dan overload jembatan gantung secara dini dengan baik.

\section{KESIMPULAN DAN SARAN}

Sistem peringatan kemiringan menara dan overload jembatan gantung menggunakan sensor kemiringan dan sensor massa skala laboratorium telah berhasil dibuat dan dapat bekerja dengan baik. sehingga dapat memberikan peringatan dini dengan baik setelah sudut terbaca melebihi $1,11^{\circ}$ dan beban melebihi 500 gram

\section{UCAPAN TERIMA KASIH}

Pada kesempatan ini penulis mengucapkan terimakasih kepada pihak-pihak yang sudah membantu terlaksananya penelitian ini. Penulis mengucapkan terimakasih kepada Laboratorium Elektronika Instrumentasi dan Geofisika dan Laboratorium Fisika Dasar Jurusan Fisika FMIPA Unsoed yang sudah menyediakan fasilitas untuk penelitian.

\section{DAFTAR PUSTAKA}

[1] Munawir, Nasution, N. C., "Pengaruh Suspender Tipe Vertical dan Inclined Terhadap Kestabilan Jembatan Gantung", Jurnal Teknik Sipil dan Konstruksi 3(2) (2017) 13-22.

[2] R. Firdaus, L. Lufti, M. H. Anshor, dan R. Kurnia, "Otomatisasi Sensor Load Cell untuk Mengatasi Overload Kendaraan", Jurnal Nasional Teknik Elektro 8(2) (2019) 81-88.

[3] S. P. Mangkoesoebroto, "Keruntuhan Jembatan Gantung Kartanegara Tragedi dalam Proses Rancang Bangun Infrastruktur", Jurnal Teknik Sipil 19(3) (2012) 207-220.

[4] W. T. Atmojo, Rancang Bangun Sistem Pengukuran Viskositas Metode Bola Jatuh Berbasis Sensor Proximity dan Load Cell, Universitas Jenderal Soedirman, Purwokerto,2020

[5] D. Q. A. R. Pahlawan, Rancang Bangun Sistem Pengukuran Kemiringan Lahan Berbasis Sensor GY-521 GyroAccelerometer MPU-6050, Universitas Jenderal Soedirman, Purwokerto, 2020. 